\title{
Radiation Functionalization of Polyethylene Glycol Films with Multiwall Carbon Nanotubes
}

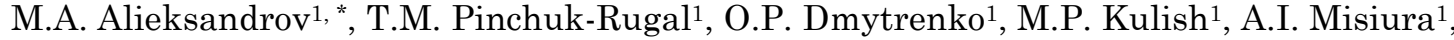 \\ A.M. Gaponov ${ }^{1}$, V.M. Popruzhko, V.V. Shlapatska ${ }^{2}$ \\ ${ }_{1}^{1}$ Taras Shevchenko National University of Kyiv, 64, Volodymyrska St., 01033 Kyiv, Ukraine \\ ${ }^{2}$ L.V. Pisarzhevski Institute of Physical Chemistry, NAS, 31, pr. Nauki, 03028 Kyiv, Ukraine
}

(Received 16 August 2020; revised manuscript received 20 October 2021; published online 25 October 2021)

\begin{abstract}
The structure, electrical conductivity and optical absorption of polyethylene glycol (PEG) films with multiwall carbon nanotubes $(\mathrm{MwNT})$ in the initial state and after radiation functionalization by means of high-energy electron irradiation $\left(E_{e}=1.8 \mathrm{MeV}\right)$ with absorption doses of 10 and $30 \mathrm{MRad}$ were studied. The structure was studied by XRD method and optical microscope. It is shown that electron irradiation significantly affects the behavior of the percolation curve. Even at an absorption dose of $10 \mathrm{MRad}$, the percolation threshold increases by almost an order of magnitude due to the formation of a network structure in the polymer matrix as a consequence of crosslinking of macromolecules. A low percolation threshold was obtained for film samples of PEG with MwNT. Two theories were used to construct the percolation curve. Fitting the experimental data for the $\sigma_{c} / \sigma_{m}$ ratio shows an increase in the value of $\varphi_{c}$ with a rise in the absorption dose, which is consistent with the scaling approximation. Changes in the optical density spectra with increasing concentration of $\mathrm{MwNT}$ in the PEG matrix before and after radiation functionalization by means of high-energy electron irradiation are shown. Radiation exposure has a complex effect on the structure and properties of polymer composites and can generate various defects in carbon nanotubes. The complex behavior of the optical absorption spectrum is due to the appearance of absorption features associated with the presence of singularities in carbon nanotubes.
\end{abstract}

Keywords: Polyethylene glycol, Carbon nanotubes, Percolation, Optical density, Electron irradiation.

DOI: $10.21272 /$ jnep.13(5).05029

PACS numbers: 72.80. $-\mathrm{r}, 73.63 . \mathrm{Fg}$

\section{INTRODUCTION}

Polyethylene glycol (PEG) belongs to polyesters that are widely used in various science-intensive industries. Their feature is a significant range of molecular weights, depending on which the polymer can be in liquid and solid physical states. Of particular interest are PEGs with low molecular weight, for example, PEG 400 , which is in the liquid state and often serves as a matrix for drugs due to non-toxicity [1-6], as well as for various fillers, including carbon nanomaterials: graphene, nanotubes, fullerenes. These fillers are able to radically affect the properties of nanocomposites with PEG [7-13]. Thus, for graphene oxide, depending on the method of preparation, in which physical or chemical bonding takes place, the electrical, dielectric and optical properties change significantly, which is accompanied by the emergence of additional optical modes in the IR absorption spectrum. When PEG is filled with multiwall carbon nanotubes (MwNT), there is a noticeable shift of the percolation threshold and other parameters of the scale dependence of electrical conductivity, which is a consequence of the formation of special structures of the conducting cluster [7-13].

It should be noted that the properties of PEG-based nanocomposites change not only depending on their molecular weight and the method of preparation, which primarily applies to film samples. Unlike bulk and liquid samples, the properties of films are poorly studied. Despite the tendency of PEG to form mesh structures, radiation functionalization of these nanocomposites, which can lead to chain crosslinking and, as a consequence, its effect on the important properties of these composites, is not considered.

The aim of this work is to study the effect of electron irradiation $\left(E_{e}=1.8 \mathrm{MeV}\right)$ on the optical absorption and percolation parameters of PEG films with MwNT to establish the mechanisms of their transformation.

\section{EXPERIMENTAL METHODOLOGY}

Films of pure PEG-400 and its composites of MwNT made by the method of temperature catalytic conversion were synthesized by the method of "Doctor blade coating". The structural formula of PEG-400 is shown in Fig. 1.

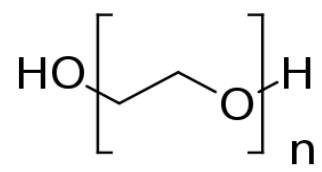

Fig. 1 - Structural formula of PEG-400

The manufacturing temperature of the films was about $180^{\circ} \mathrm{C}$. The thickness of PEG and PEG-MwNT films was 100-200 $\mu \mathrm{m}$, the concentration of MwNT was 0.2-1.0 wt. $\%$.

The structure of PEG was studied using an X-ray diffractometer DRON-3M (Russia), $\lambda_{\mathrm{CuK}_{\alpha 1,2}}=0.154178 \mathrm{~nm}$.

The resistivity of PEG and PEG-MwNT films was determined using a UNI T71 multimeter (Uni Trend Group (UNI-T), China) and a PICOTEST m3500 recording picovoltmeter. The applied voltage was $\pm 0.5 \mathrm{~V}$ with a step of $0.005 \mathrm{~V}$. The transition to electrical con-

\footnotetext{
*mrmarafon@gmail.com
} 
ductivity was carried out according to the formulas:

$$
\Delta U=U_{1}-U_{2}, \Delta I=I_{1}-I_{2},
$$

where $\Delta U$ and $\Delta I$ are the differences between voltage and current, respectively.

$$
R=|\Delta U / \Delta I|,
$$

where $R$ is the resistance (Ohm).

$$
\sigma=1 / \rho
$$

$\rho=R \cdot 65 \cdot 10^{-6}$ is the resistivity $(\mathrm{Ohm} \cdot \mathrm{m}), 65 \cdot 10^{-6}$ is the film size constant.

The optical absorption spectra of the films were recorded using a Lumsail 723PC spectrophotometer (Lumsail, China) in the wavelength range $320-110 \mathrm{~nm}$ and a scanning step of $1 \mathrm{~nm}$.

Radiation functionalization of the films was performed using a linear electronic accelerator ILU-6 (Russia). The electron energy was $E_{e}=1.8 \mathrm{MeV}$, the absorption dose was equal to 10 and 30 MRad.

\section{RESULTS AND DISCUSSION}

Optical microscopy of PEG-MwNT films shows an uneven distribution of nanotubes in the form of intertwined strands. At the same time, already at a concentration $\varphi=0.0009$ vol. part. $(0.2$ wt. \%) MwNT, the formation of leading clusters was observed. Despite slight differences at lower concentrations of MwNT, the pattern of distribution of nanotubes is maintained up to the maximum value $\varphi=0.0049$ vol. part. (1.0 wt. \%). An optical image of the placement of nanotube strands for films with $\varphi=0.0049$ vol. part. (1.0 wt. \%) MwNT is shown in Fig. 2.

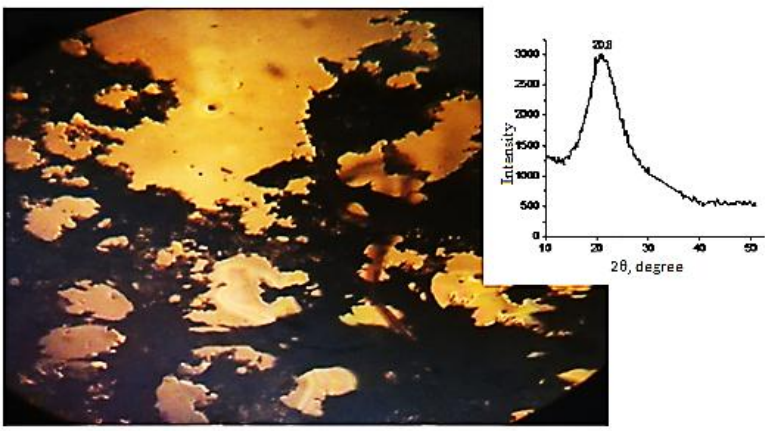

Fig.2 - Optical image of the distribution of composite PEG MwNT with $\varphi=0.0049$ vol. part. (1.0 wt. \%) (the insert shows the X-ray diffraction pattern of the film of unfilled PEG, film thickness $d=200 \mathrm{~nm}, \lambda_{\mathrm{CuK}_{\alpha 1,2}}=0.154178 \mathrm{~nm}$ )

The X-ray diffraction pattern for the film of unfilled PEG indicates the formation of the amorphous phase of the polymer, which also occurs for bulk samples [7].

The above distribution of nanotubes indicates that as a result of the emergence of leading clusters at concentrations greater than $\varphi=0.0009$ vol. part. (0.2 wt. \%) MwNT, the percolation effect is realized at a lower filler content.

Fig. 3 shows the percolation curves for PEG-MwNT films before and after electron irradiation with differ- ent absorption doses.

The description of the percolation dependence was adjusted using the scaling equation:

$$
\sigma=\sigma_{0}\left(\varphi-\varphi_{c}\right)^{t}, \varphi>\varphi_{c}
$$

where $\sigma_{0}$ is the pre-exponent, $t$ is the critical index, $\varphi_{c}$ is the percolation threshold.

The fit to describe the results leads to the most correct agreement of the parameters of the scale dependence, which differ for nanocomposites irradiated with different absorption doses. Thus, for non-irradiated films, the parameter values are $\sigma_{0}=2.34 \mathrm{Sm} / \mathrm{m}, t=3.2$, $\varphi_{c}=0.0003$ vol. part. An important feature of these parameters is the low value of the percolation threshold $\varphi_{c}$. This value differs significantly from the case of bulk samples of PEG [8-12] and corresponds to composites with segregated distribution of nanotubes for $\mathrm{PE}$ and PVC [14-17]. It should be noted that the methods of preparation of PEG films and bulk disc-shaped
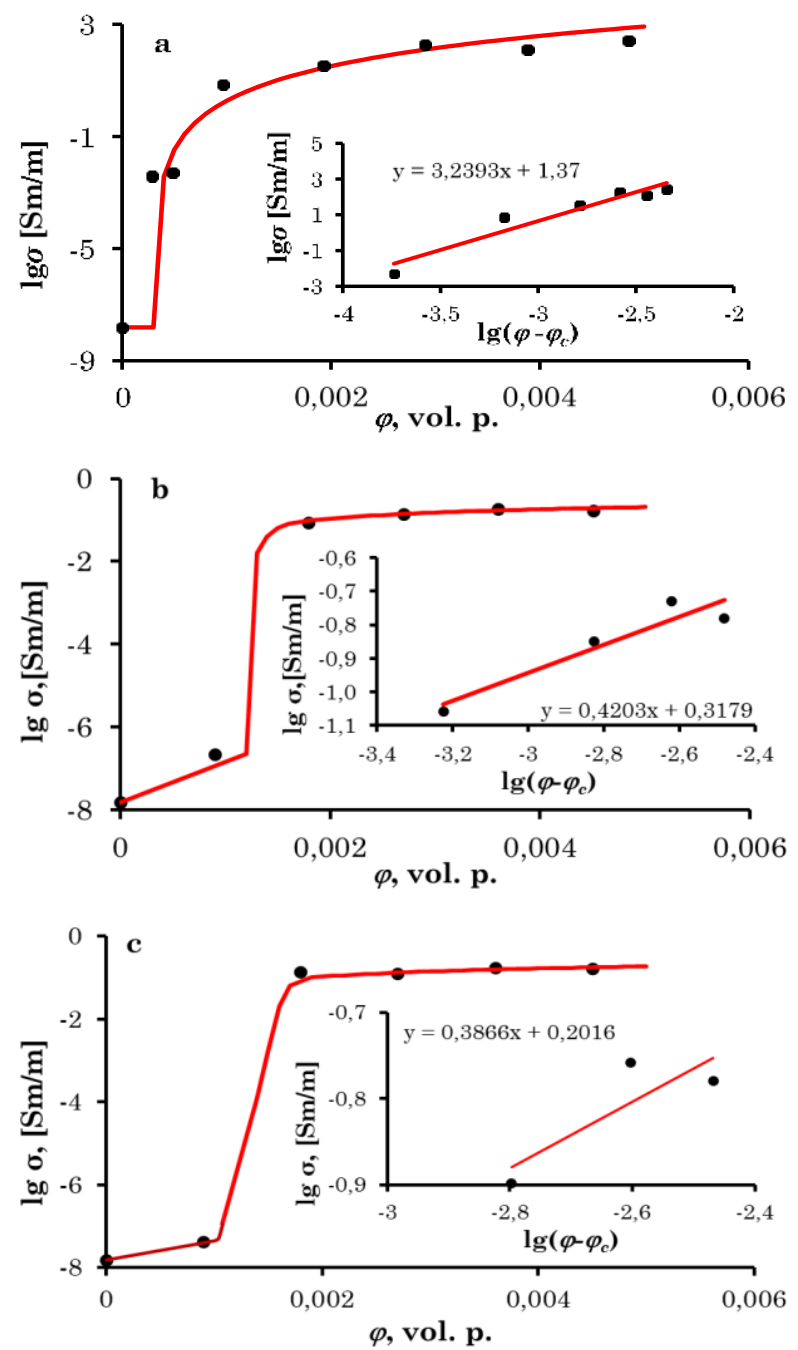

Fig.3 - Dependences of static conductivity (on a logarithmic scale) for PEG films with different contents of MwNT $(d=200 \mathrm{~nm}$, before (a) and after electron irradiation with absorption doses of 10 (b) and 30 (c) MRad); the insets show linear dependences of electrical conductivity on $\varphi \sim \varphi_{c}$, where $\varphi_{c}$ - the percolation threshold, circles - experimental data, solid line - fit to the scale dependence) 
samples of PE and PVC differ. At the same time, the parameter $t$ is close to the value $t=2.0$, which is characteristic of the random distribution of fillers. Electron irradiation with an absorption dose of 10 MRad significantly affects the behavior of the percolation curve. Fitting the experimental data to the scale dependence leads to the following parameter values: $\sigma_{0}=2.08 \mathrm{Sm} / \mathrm{m}, t=0.41$, and $\varphi_{c}=0.0012$ vol. part. The obtained parameters are very different from the values inherent in the irradiated sample. Thus, $t=0.41$ differs significantly from $t=2.0$, so there is a deterioration in the dispersion of the distribution of nanotubes. The percolation threshold increases by almost an order of magnitude but remains insignificant. The value of electrical conductivity decreases by several orders of magnitude at nanotube concentrations in the range of its percolation growth. This behavior of the percolation curve, as can be assumed, is due to the formation of a mesh structure in the polymer matrix, as a consequence of crosslinking of macromolecules, which prevents the formation of a conductive cluster similar to non-irradiated samples.

If the absorption dose increases to $30 \mathrm{MPa}$, there is a further adjustment of the percolation curve. The fitting parameters are the following: $\sigma_{0}=1.59 \mathrm{Sm} / \mathrm{m}$, $t=0.39$, and $\varphi_{c}=0.001$ vol. part.

Fig. 4 shows the dependences of $\lg \left(\sigma_{c} / \sigma_{m}\right)$, which reflect the ratio of the static electrical conductivity $\sigma_{c}$ for PEG-MwNT nanocomposites with different contents of nanotubes to its maximum value $\sigma_{m}$, on $\varphi$, vol. part. for unirradiated and irradiated composites.

The experimental data on the ratio $\sigma_{c} / \sigma_{m}$ were adjusted in accordance with the following equation [12]:

$$
\lg \left(\sigma_{c} / \sigma_{m}\right)=A\left(1-e^{-\alpha \varphi}\right)^{n}
$$

As a result, the following parameter values were obtained for unirradiated nanocomposites:

$$
A=10 ; \alpha=39 ; n=9 ; \varphi_{c}=0.0006 \text { vol. part. }
$$

At an absorption dose of $10 \mathrm{MRad}$, these parameters are equal to:

$$
A=6.8 ; \alpha=17 ; n=5.5 ; \varphi_{c}=0.0010 \text { vol. part. }
$$

As the absorption dose increases to $30 \mathrm{MRad}$, these parameters change to values:

$$
A=6.8 ; \alpha=25.8 ; n=15 ; \varphi_{c}=0.0011 \text { vol. part. }
$$

It is seen that with minor changes in the parameters $A$, which are responsible for the scale, parameters $a$ associated with the slope of the percolation region, $n$ caused by the length of the curve in the pre-percolation region, and the slope of the curve undergo a more significant adjustment. In addition, there is a significant change in the percolation threshold $\varphi_{c}$. In this case, $\varphi_{c}$ increases with increasing absorption dose, which is consistent with the scaling approximation.

Filling of PEG films with nanotubes and radiation functionalization lead to a rearrangement of the optical absorption spectra.

Fig. 5 shows the spectra of optical density for pure PEG films and their nanocomposites with MwNT without radiation exposure and at two values of electron irradiation doses.

For pure non-irradiated PEG films, two maxima of optical density of about 366 and $436 \mathrm{~nm}$ are observed.
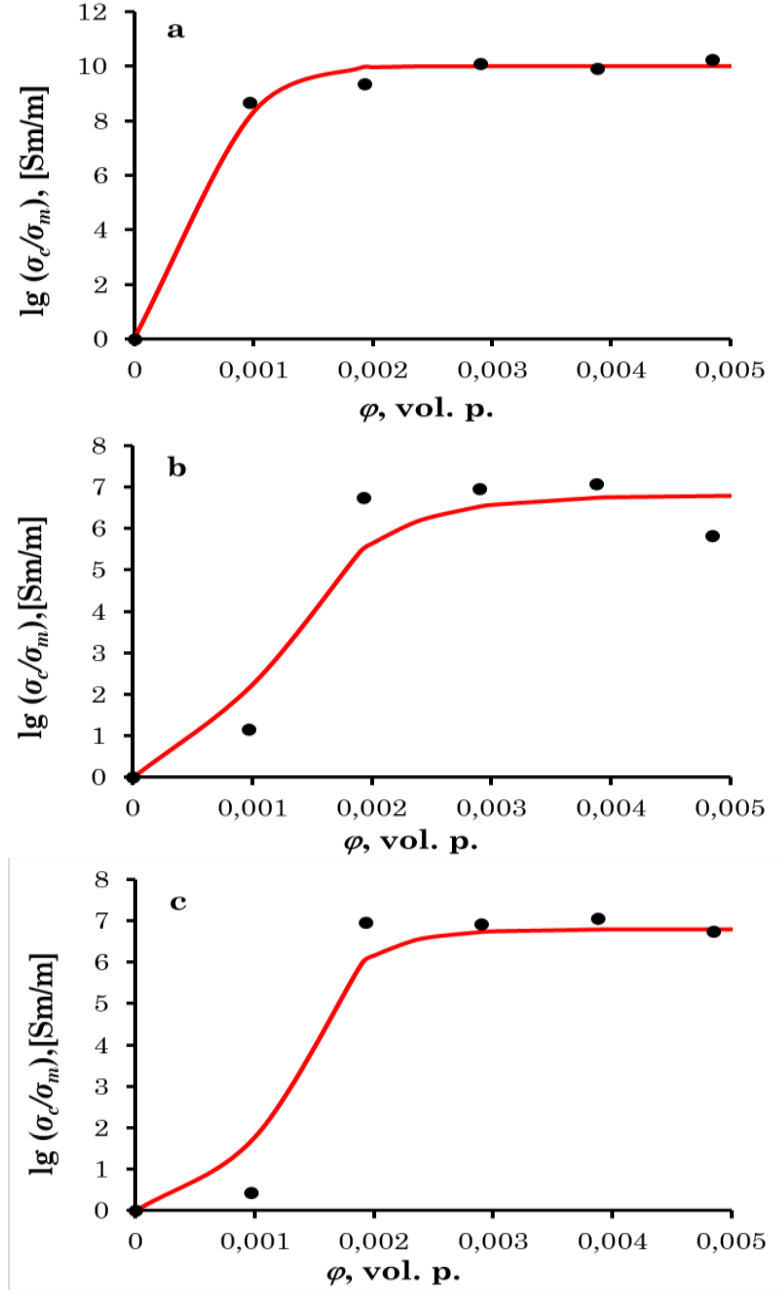

Fig. 4 - Dependences of the ratio of the electrical conductivity of PEG-MwNT nanocomposites on the content of nanotubes for unirradiated (a) and irradiated with electrons with absorption doses of 10 (b) and 30 (c) MRad, $E_{e}=1.8 \mathrm{MeV}$

In PEG-MwNT nanocomposites, an increase in the filler concentration is accompanied by a decrease in optical density, a shift and transformation of absorption maxima. Thus, at a concentration of $0.2 \mathrm{wt} \%$ MwNT, the maximum optical density shifts to $349 \mathrm{~nm}$ and an inflection appears at about $400 \mathrm{~nm}$. Subsequently, the number of inflections increases, and the optical density maxima expand. This is especially noticeable at a content of 1.0 wt. \% MwNT. It is assumed that in the absence of radiation functionalization, the complex behavior of the optical absorption spectrum is due to the appearance of absorption features associated with the presence of singularities in nanotubes [20].

Radiation functionalization of PEG-MwNT nanocomposites is a complex process that includes the effect of electron irradiation on the structure of the polymer matrix, as well as on the occurrence of various defects in carbon nanotubes. As the MwNT content changes, each of these effects will affect the electronic structure of pure PEG and its nanotube composites differently.

As a result of irradiation of pure PEG film at absorption doses of 10 and $30 \mathrm{MRad}$, there is a slight decrease in optical density and a significant shift of absorption peaks, which indicates a change in the 

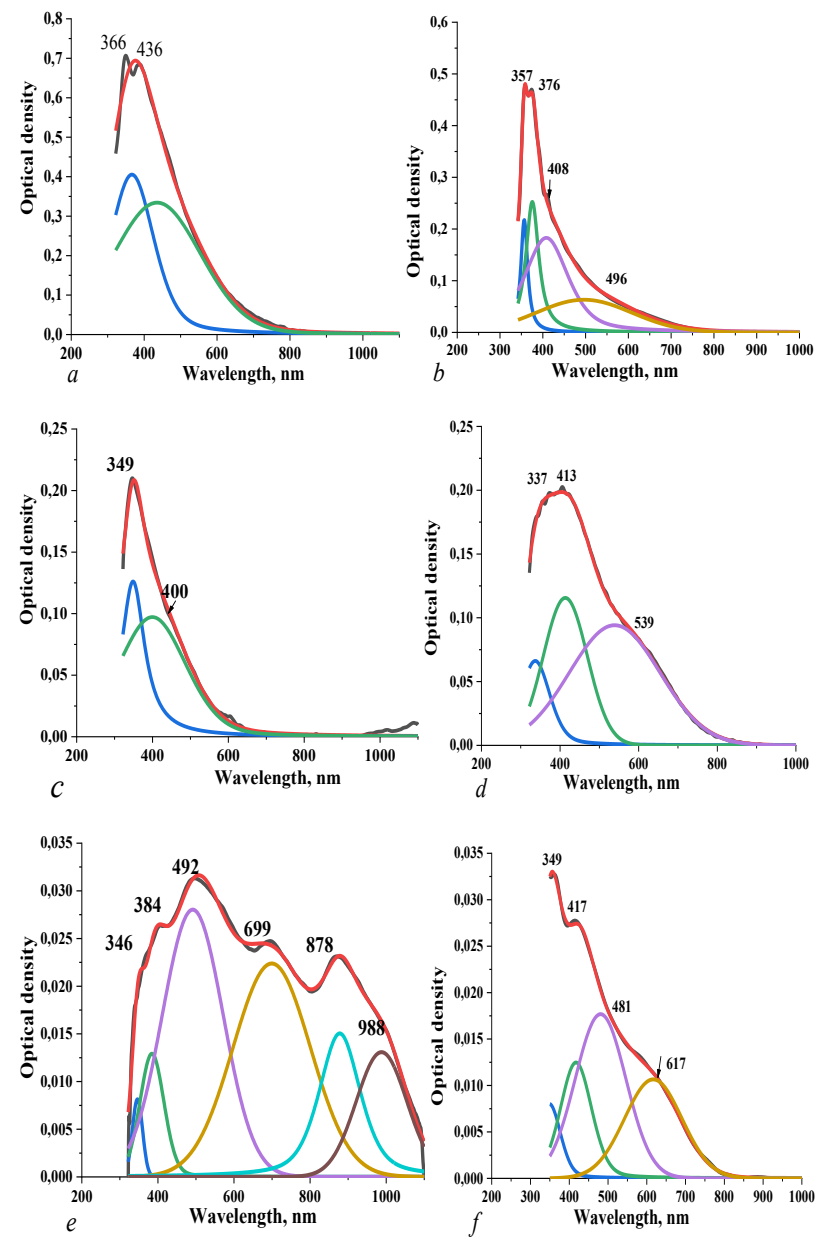

Fig. 5 - Optical density spectra of pure PEG films (a, b), PEGMwNT films with MwNT concentration: c, d-0.2 wt. \%; e, f$1 \mathrm{wt} . \%$; in the unirradiated state (a, c, e), and after electron irradiation with an absorption dose of $10(\mathrm{~b}, \mathrm{~d}, \mathrm{f})(d=200 \mathrm{~nm}$, $T=298 \mathrm{~K}, E_{e}=1.8 \mathrm{MeV}$ )

\section{REFERENCES}

1. P. Mishra, B.Nayak, R.K. Dey, Asian J. of Pharm. Sci. 11, 337 ( 2016)

2. A. D'souza, R. Shegokar. Expert Opin. Drug Deliv. 13, 1257 (2016).

3. P.L. Turecek, M.J. Bossard, F. Schoetens, I.A. Ivens, J. Pharm. Sci. 105, 460 (2016).

4. A.I. Abdelamir, E. Al-Bermany, F.Sh. Hashim, J. Phys.: Conf. Ser. 1294, 022029 (2019).

5. J. Charmi, H. Nosrati, J.M. Amjad, R. Mohammadkhani, H. Danafar, Heliyon 5, e01466 (2019).

6. P.A. Putro, L. Roza, I. Isnaeni, Indonesian J. Sci. Educ. 3 , 76 (2019).

7. B.M. Abu-Zied, M.A. Hussein, A.M. Asiri, Int. J. Electrochem. Sci. 10, 4873 (2015).

8. E.A. Lesenkov, Yu.V. Yakovlev, V.V. Klepko, Ukr. J. Phys. 58 No 4, 378 (2018).

9. E.A. Lesenkov, V.V. Klepko, Yu.V. Yakovlev, Ukr. Polymer J. 35 No 3, 259 (2013).

10. Yu.V. Yakovlev, V.V. Klepko, E.A. Lysenkov, Ukr. Polymer J. 36 No 1, 53 (2014).

11. E.A. Lesenkov, Yu.V. Yakovlev, V.V. Klepko, J. Nano- structure of PEG as a result of mesh formation. For a nanocomposite with $0.2 \mathrm{wt} . \% \mathrm{MwNT}$, the spectrum is complicated both in the region of the absorption peak and due to the appearance of a marked inflection in the optical density spectrum at about $539 \mathrm{~nm}$. Similar changes occur for nanocomposites with $0.4,0.6$, and 0.8 wt. $\%$ and they are more significant at the highest concentration of $1.0 \mathrm{wt}$. \% MwNT. For the latter nanocomposite, the appearance of inflections in the optical density spectrum is more pronounced.

At the same time, the optical density spectrum for the irradiated nanocomposite with $1.0 \mathrm{wt} . \% \mathrm{MwNT}$ is less complex compared to the non-irradiated film. It can be assumed that radiation functionalization for nanocomposites with a high content of carbon nanotubes leads not only to the appearance of a mesh structure of the polymer matrix, but also to manifestations of the generation of radiation defects. At both doses of radiation functionalization, the singular features of carbon nanotubes are lost.

\section{CONCLUSIONS}

Optical microscopy of PEG-MwNT films shows an uneven distribution of nanotubes in the form of intertwined strands. At a concentration of 0.2 wt. \% MwNT in the films, the formation of leading clusters is observed. It is established that due to the formation of leading clusters for PEG-MwNT films, the value of the percolation threshold is $\varphi_{c}=0.0003$ vol. part. Radiation functionalization significantly affects the behavior of the percolation curve. At an absorption dose of $10 \mathrm{MRad}, \varphi_{c}=0.0012$ vol. part due to the formation of a mesh structure in the polymer matrix due to crosslinking of macromolecules. It is shown that for PEG-MwNT films in the initial state and after electron irradiation, there is a complex behavior of optical absorption spectra, which is associated with the presence of singularities in carbon nanotubes.

Electron. Phys. 7, 01031 (2015).

12. E.A. Lesenkov, V.V. Klepko J. Phys. Stud. 3702 (2016).

13. E.A. Lysenkov, V.V. Klepko, Yu.V. Yakovlev, Elektronnaya obrabotka materialov 52 No 2, 62 (2016) [In Russian].

14. O.S. Nychyporenko, T.M. Pyinchuk-Rugal', D.O. Koval'ova, O.P. Dmytrenko, M.P.Kulyish, Ye.P. Mamunya, V.V. Levchenko, V.V. Shlapats'ka, Probl. At. Sci. Technol. 4 No 92, 44 (2014).

15. O.S. Nychyporenko, O.P. Dmytrenko, M.P. Kulyish, T.M. Pyinchuk-Rugal', M.A. Zabolotnij, Ye.P. Mamunya, V.V. Levchenko, V.V. Shlapats'ka, V.V. Strel'chuk, V.M. Tkach, Probl. At. Sci. Technol. 2 No 102, 99 (2016).

16. T.M. Pinchuk-Rugal, O.P. Dmytrenko, M.P. Kulish, Yu.I. Prylutskyy, O.S. Nychyporenko, M.I. Shut, V.M. Tkach, V.V. Shlapatska, NANO 2016, Springer Proceeding in Physics 195, 757, (2017).

17. M.A. Alieksandrov, T.M. Pinchuk-Rugal, O.P. Dmytrenko, M.P. Kulish, V.M. Popruzhko, Ye.P. Mamunya, V.V. Strelchuk, Nanosistemi, Nanomateriali, Nanotehnologii 16, 737 (2018).

18. A. Tomova, G. Gentile, A. Grozdanov, M.E. Errico, P. Paunovic, M. Avella, A.T. Dimitrov, Acta Phys. Pol. A 129, 405 (2016). 


\title{
Радіаційна функціоналізація плівок поліетиленгліколю з багатостінними вуглецевими нанотрубками
}

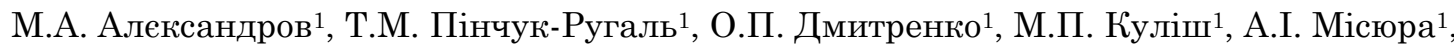 \\ A.M. Гапонов ${ }^{1}$, B.M. Попружко ${ }^{1}$, В.В. Шлапацька ${ }^{2}$
}

${ }^{1}$ Київський національний університет імені Тараса Шевченка, вул. Володимирська, 64, 01033 Київ, Україна 2 Інститут фіззиної хімії імені Л.В. Писаржевського НАНУ, проспект Науки, 31, 03028 Київ, Україна

Досліджено структуру, електропровідність та оптичне поглинання плівок поліетиленгліколю (ПЕГ) з багатостінними вуглецевими нанотрубками (БВНТ) у вихідному стані та після радіаційної функціоналізації за допомогою високоенергетичного електронного опромінення $\left(E_{e}=1.8 \mathrm{MeB}\right)$ з дозами поглинання 10 та $30 \mathrm{MPaд.} \mathrm{Структуру} \mathrm{досліджено} \mathrm{за} \mathrm{допомогою} \mathrm{оптичного} \mathrm{мікроскопа} \mathrm{та} \mathrm{рентге-}$ ноструктурного аналізу. Показано, що електронне опромінення істотно впливае на поведінку перколяційної кривої. Вже за дози поглинання 10 МРад поріг перколяції зростае майже на порядок, що обумовлено формуванням сітчастої структури в полімерній матриці, як наслідок зшивання макромолекул. Отримано низькі значення порогу перколяції для плівкових зразків ПЕГ з БВНТ. Для побудови теоретичних кривих використано дві теорії. За допомогою підгонки експериментальних даних відношення $\sigma_{c} / \sigma_{m}$, встановлено зростання $\varphi_{c}$ зі збільшенням дози поглинання, що узгоджуеться зі скейлінговим наближенням. Показано зміни у спектрах оптичного поглинання з ростом концентрації БВНТ в матриці ПЕГ перед та після функціоналізації за допомогою високоенергетичного електронного опромінення. Радіаційне опромінення складним чином впливае на структуру та властивості полімерних композитів та може генерувати різноманітні дефекти у вуглецевих нанотрубках. Складна поведінка спектру оптичного поглинання обумовлена появою особливостей поглинання, пов'язаних з наявністю сингулярностей у вуглецевих нанотрубках.

Ключові слова: Поліетиленгліколь, Вуглецеві нанотрубки, Перколяція, Оптична густина, Електронне опромінення. 